\title{
Factors predicting the early mortality of trauma patients
}

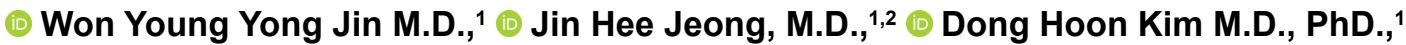

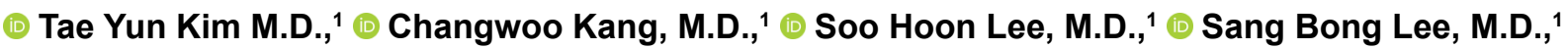

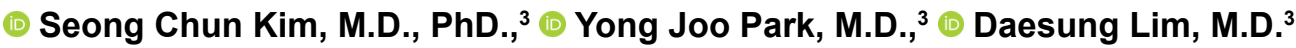

\begin{abstract}
1'Department of Emergency Medicine,Gyeongsang National University School of Medicine, Jinju-si, Gyeongsangnam-do-Republic of Korea ${ }^{2}$ Gyeongsang Institute of Health Sciences, Gyeongsang National University School of Medicine, Jinju-si, Gyeongsangnam-do-Republic of Korea ${ }^{3}$ Department of Emergency Medicine, Gyeongsang National University School of Medicine and Gyeongsang National University Changwon Hospital, Changwon, Gyeongsangnam-Republic of Korea
\end{abstract}

\begin{abstract}
BACKGROUND: The aim of this study was to identify factors predicting early mortality in trauma patients.

METHODS: This was a study of 6288 trauma patients admitted to the hospital between July 2011 and June 2016. Among the variables recorded for a prospective trauma registry, the following were selected for analysis: sex; age; a combination of the Glasgow Coma Scale score, age, and systolic blood pressure (SBP) (GAP); a combination of the mechanism of injury, the Glasgow Coma Scale score, age, and SBP (MGAP); SBP; respiratory rate; peripheral oxygen saturation $\left(\mathrm{SpO}_{2}\right.$ value); the Glasgow Coma Scale score; laboratory variables; and presentation time. Logistic regression analysis was used to explore associations between these variables and early mortality.
\end{abstract}

RESULTS: In total, 296 (4.6\%) patients died within 24 hours. Univariate regression analysis indicated that age, the GAP, the MGAP, $\mathrm{SBP}, \mathrm{SpO}_{2}$, the Glasgow Coma Scale score, base excess, hemoglobin level, platelet count, INR, and presentation time predicted early mortality. Multivariate regression showed that the GAP, the MGAP, $\mathrm{SPO}_{2}$, base excess, platelet count, and INR were independently predictive. The areas under the receiver operator curve comparisons for the GAP and MGAP models revealed the superiority of the GAP-based model.

CONCLUSION: The GAP model, $\mathrm{SpO}_{2}$, base excess, platelet count, and INR predicted the early mortality of trauma patients.

Keywords: Acute traumatic coagulopathy; base excess; mortality; peripheral oxygen saturation; trauma; trauma scoring system.

\section{INTRODUCTION}

Trauma is a serious global medical and economic issue, accounting for $10 \%$ of all mortality worldwide. ${ }^{[1,2]}$ Many studies of trauma-related death have been performed, including the establishment of trauma scoring systems (TSSs) and the evaluation of coagulopathy associated with bleeding and nontrauma-related factors, such as the time of presentation to emergency departments (EDs). ${ }^{[3-5]}$

Over the past 40 years, TSSs have been developed to rate trauma severity and predict mortality. These include the In- jury Severity Score (ISS); the Trauma-related Injury Severity Score (TRISS); the Revised Trauma Score (RTS); the Mechanism, Glasgow Coma Scale, Age, and Systolic Blood Pressure (MGAP) Score; and the Glasgow Coma Scale, Age, and Systolic Blood Pressure (GAP) Score. Of these, the MGAP and GAP systems are more recent additions. They are simple, rapid scoring systems that are more accurate than other TSSs in the prediction of trauma-associated mortality. ${ }^{[3,6-9]}$

Bleeding and coagulation disorders cause most preventable trauma-related mortality. Over the last 10 years, the number of studies of acute traumatic coagulopathy (ATC) has

Cite this article as: Jin WYY, Jeong JH, Kim DH, Kim TY, Kang C, Lee SH, et al. Factors predicting the early mortality of trauma patients. Ulus Travma Acil Cerrahi Derg 2018;24:532-538.

Address for correspondence: Jin Hee Jeong, M.D.

79, Gangnam-ro 52727 jinju-si - South Korea

Tel: 82-10-4846-9592 E-mail: pernoctans@gmail.com

Ulus Travma Acil Cerrahi Derg 2018;24(6):532-538 DOI: 10.5505/tjtes.2018.29434 Submitted: 16.04.2018 Accepted: 16.07.2018 Online: 01.1I.2018

Copyright 2018 Turkish Association of Trauma and Emergency Surgery 
increased significantly. ATC independently predicts mortality and is commonly encountered during the treatment of trauma patients. ${ }^{[4,10,11]}$

Recently, ED presentation time, which is an indicator of treatment quality, has become a topic of interest. ${ }^{\left[{ }^{[2]}\right.}$ A study has explored whether presentation time was associated with prognosis. ${ }^{[13]}$ Several studies have explored whether traumaassociated in-hospital mortality differed in those admitted during business and non-business hours. Although the results varied somewhat, no remarkable difference was noted. ${ }^{[5,14]}$

However, these studies related to TSSs, ATC, and ED presentation time evaluated only in-hospital or 30-day mortality, not early mortality. The major causes of early and late mortality caused by trauma are different. Most early mortality is caused by bleeding and brain injuries, whereas most late mortality is attributable to complications developing in the hospital, such as infection and multiple organ failure (MOF). [15] The associated factors may differ. Predictive factors are needed, since most deaths from trauma are cases of early mortality. ${ }^{[16,17]}$ These factors should be readily identifiable in the early phase of management. Indeed, if such factors could be promptly identified, trauma patients could receive more aggressive treatment. Thus, factors that could rapidly predict early mortality were the subject of this study.

\section{MATERIALS AND METHODS}

\section{Study Design}

Data in a prospectively recorded trauma registry were retrospectively reviewed to identify 24-hour mortality and early predictors thereof. Professional health information managers, closely supervised by emergency physicians, maintain the ED trauma registry of our 900-bed tertiary care university hospital. All ED patients are managed by board-certified emergency physicians. This study was approved by the Gyeongsang National University Hospital Institutional Review Board.

\section{Patient Information}

Patients aged $\geq 16$ years with blunt or penetrating trauma admitted to the ED of a single hospital between July 20II and June 2016 were evaluated. The exclusion criteria were other forms of trauma, trauma of unknown type, and dead-on-arrival status (whether or not cardiopulmonary resuscitation was attempted). Patients who were discharged or transferred to another hospital within 24 hours of arrival were also excluded.

\section{Variables}

Among the many possible variables, those that have usefully predicted trauma mortality in previous studies and could be quickly scored (within 30 minutes) were selected for analysis. Variables exhibiting significant correlations (multicollinearity) were excluded. Sex, age, the GAP, the MGAP, systolic blood pressure (SBP), respiratory rate (RR), peripheral oxygen saturation $\left(\mathrm{SpO}_{2}\right)$ level, the Glasgow Coma Scale (GCS) score, base excess, hemoglobin $(\mathrm{Hb})$ level, platelet count, international normalized ratio (INR), and presentation time were evaluated. The first measurement taken after ED presentation was used in this study. The GAP and MGAP reliably predict trauma-related mortality and can be readily calculated even in busy EDs (Table I). ${ }^{[8,9]}$ Presentation time was classified as a weekday or not a weekday. Weekdays were defined as Monday to Friday from 09:00 to 17:59. Early mortality was defined as mortality within 24 hours of presentation. The primary outcomes were early mortality and factors predicting such mortality.

\section{Statistical Analysis}

Multivariate imputation by chained equation was used to impute missing values. ${ }^{[18]}$ Sex, age, the GAP, the MGAP, SBP, RR, $\mathrm{SpO}_{2}$, the GCS, Hb level, platelet count, INR, and presentation time were subjected to univariate analysis, and factors identified as significant were then subjected to multivariate analysis (with the exceptions of age and SBP because both feature in the GAP and MGAP). Multivariate logistic regression was performed twice, including either the GAP or the MGAP and other variables identified as significant by the univariate analysis. The equation used to calculate predicted survival (Ps) was: $P s=1 /(I+e-b), b=b 0+b l \times G A P+b 2 \times \operatorname{sex}$ $+b 3 \times$ INR... (thus including coefficients b0, bI, b2, b3...). The coefficients were derived during multivariate regression analysis. The discriminatory ability of the final models was evaluated by drawing receiver operator characteristic curves and a comparison of the curves using the method of DeLong et al. ${ }^{[19]}$

The ease of deriving the variables of the final model was also assessed. The cutoffs were the 3 GAP groups (mild, moderate, and severe), INR 1.5, platelet count $<100,000 / \mu \mathrm{L}$, base excess -6 , and the 6 saturation groups (>91\%, $90-81 \%$,

Table I. GAP and MGAP scoring systems

\begin{tabular}{lccc}
\hline GAP & Points & MGAP & Points \\
\hline GCS & $3-15$ & GCS & $3-15$ \\
Age (years) & & Age (years) & \\
$\quad<60$ & 3 & $<60$ & 5 \\
$>60$ & 0 & $>60$ & 0 \\
SBP (mmHg) & & SBP (mmHg) & \\
$>120$ & 6 & $>120$ & 5 \\
$60-120$ & 4 & $60-120$ & 3 \\
$<60$ & 0 & $<60$ & 0 \\
& & Blunt trauma & 4 \\
\hline
\end{tabular}

GAP: Glasgow Coma Scale, Age, and Systolic Blood Pressure; GCS: Glasgow Coma Scale; MGAP; Mechanism, Glasgow Coma Scale, Age, and Systolic Blood Pressure. 
80-71\%, 70-61\%, 60-51\%, <50\%) derived in previous studies. ${ }^{[1,9,20-22]}$ A p value $<0.05$ was considered statistically significant. MedCalc 17 (MedCalc BVBA, Ostend, Belgium) and Stata version 13 (StataCorp LP, College Station, TX, USA) software were used for the analysis.

\section{RESULTS}

\section{Baseline Characteristics}

In total, 45,589 trauma patients were admitted to the ED during the study period, and 26,202 patients $\geq 16$ years of age with blunt/penetrating trauma were included. After excluding those who had experienced cardiac arrest prior to presentation and those discharged or transferred within 24 hours, a total of 6288 patients remained (Fig. I). The mean patient age was $57.3 \pm 18.6$ years, and $67.1 \%$ were male. Baseline data (and the percentages of missing data) are shown in Table 2.

\section{Univariate and Multivariate Logistic Regression}

The 24-hour mortality rate of the study patients was $4.6 \%$. No significant between-group difference in sex was noted (males $67.0 \%$ vs. females $68.9 \%$; $\mathrm{p}=0.49$ ). However, a significant difference was observed in terms of age ( 56.90 vs. 64.56 years, $p<0.001)$. Univariate logistic regression showed that age, the GAP, the MGAP, SBP, SpO , the GCS, base excess, $\mathrm{Hb}$ level, platelet count, INR, and presentation time predicted 24-hour mortality (Table 3).

The results of the two multivariate logistic regression analyses are shown in Table 4. Both the GAP and the MGAP were significant, whereas neither $\mathrm{Hb}$ level nor presentation time was significant. Two GAP and MGAP models were created using $\mathrm{SpO}_{2}$, base excess, platelet count, and INR values. The GAP-based model afforded good discrimination [area under the receiver operator characteristic curve (AUROC): 0.962; $\mathrm{P}<0.00 \mathrm{I}$; 95\% confidence interval (Cl): 0.94-0.973]. The MGAP-based model also afforded good discrimination (AUROC 0.958; $\mathrm{p}<0.00 \mathrm{I}$; 95\% Cl: 0.946-0.970). AUROC comparisons revealed the superiority of the GAP-based

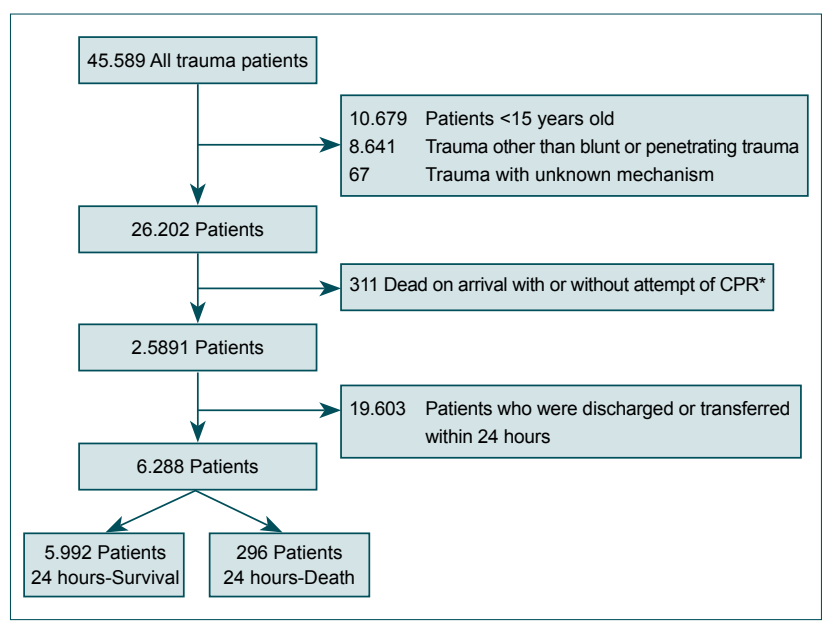

Figure 1. Study patients. CPR: Cardiopulmonary resuscitation. model ( $p<0.001$; 95\% Cl: 0.003-0.005; absolute difference: 0.00383).

A categorical model using the GAP was created because it is easy to apply (Table 5). GAP $<19$ points, INR $>1.5$, platelets count $<100,000 / \mu \mathrm{L}$, base excess $<-6$, and saturation $<90 \%$

Table 2. Baseline characteristics and missing data percentages

\begin{tabular}{lcc}
\hline Variables & $\begin{array}{c}\text { Total patients } \\
(\mathbf{n}=6288)\end{array}$ & $\begin{array}{c}\text { Missing case } \\
\mathbf{n}(\%)\end{array}$ \\
\hline Sex (male, \%) & $4217(67.1)$ & $0(0)$ \\
Age (years) & 57.26 & $0(0)$ \\
GAP & 20.76 & $22(0.3)$ \\
MGAP & 24.63 & $22(0.3)$ \\
Systolic blood pressure $(\mathrm{mmHg})$ & 131.99 & $6(0.1)$ \\
Respiratory rate (cpm) & 19.90 & $0(0)$ \\
SpO ${ }_{2}$ \%) & 96.75 & $240(3.8)$ \\
GCS & 14.11 & $16(0.3)$ \\
Base excess (mmol/L) & -2.24 & $680(10.8)$ \\
Hemoglobin level (g/dL) & 12.83 & $93(1.5)$ \\
Platelet count $\left(10^{3} / \mathrm{mm}^{3}\right)$ & 233.65 & $93(1.5)$ \\
International normalized ratio & 1.14 & $616(9.8)$ \\
Presentation time (weekday, \%) & $2662(42.3)$ & $0(0)$ \\
\hline
\end{tabular}

GAP: Glasgow Coma Scale, Age, and Systolic Blood Pressure; GCS: Glasgow Coma Scale; INR: International normalized ratio; MGAP: Mechanism, Glasgow Coma Scale, Age, and Systolic Blood Pressure; $\mathrm{SpO}_{2}$ : Peripheral oxygen saturation.

Table 3. Univariate analysis for factors associated with early mortality

\begin{tabular}{|c|c|c|c|}
\hline Variables & $\beta$ & $\mathbf{p}$ & $95 \% \mathrm{Cl}$ \\
\hline Sex (male) & -0.089 & 0.487 & $-0.34 I-0.163$ \\
\hline Age (years) & 0.025 & $<0.001$ & $0.018-0.032$ \\
\hline GAP & -0.464 & $<0.001$ & $-0.498--0.430$ \\
\hline MGAP & -0.446 & $<0.001$ & $-0.479--0.412$ \\
\hline Presentation time & 0.272 & 0.028 & $0.030-0.515$ \\
\hline $\mathrm{SBP}(\mathrm{mmHg})$ & -0.022 & $<0.001$ & $-0.026--0.018$ \\
\hline Respiratory rate (cpm) & 0.005 & 0.808 & $-0.033-0.042$ \\
\hline $\mathrm{SpO}_{2}(\%)$ & -0.135 & $<0.001$ & $-0.154-0.117$ \\
\hline GCS & -0.449 & $<0.001$ & $-0.480--0.418$ \\
\hline Base excess (mmol/L) & -0.224 & $<0.001$ & $-0.246--0.201$ \\
\hline Hemoglobin level (g/dL) & -0.323 & $<0.001$ & $-0.37 \mid--0.275$ \\
\hline Platelet count $\left(10^{3} / \mathrm{mm}^{3}\right)$ & -0.009 & $<0.001$ & $-0.011--0.007$ \\
\hline INR & 0.838 & $<0.001$ & $0.669-1.006$ \\
\hline
\end{tabular}

Cl: Confidence interval; GAP: Glasgow Coma Scale, Age, and Systolic Blood Pressure; GCS: Glasgow Coma Scale; INR: International normalized ratio; MGAP: Mechanism, Glasgow Coma Scale, Age, and Systolic Blood Pressure; $\mathrm{SpO}_{2}$ : Peripheral oxygen saturation. 
Table 4. Multivariate analysis for factors associated with early mortality

\begin{tabular}{|c|c|c|c|c|c|c|c|}
\hline Variables & $\beta$ & $\mathbf{p}$ & $95 \% \mathrm{Cl}$ & Variables & $\beta$ & $\mathbf{p}$ & $95 \% \mathrm{Cl}$ \\
\hline GAP & -0.415 & $<0.001$ & $-0.452--0.378$ & MGAP & -0.399 & $<0.001$ & $-0.435--0.362$ \\
\hline Presentation time & 0.222 & 0.215 & $-0.129-0.573$ & Presentation time & 0.280 & 0.112 & $-0.065-0.625$ \\
\hline $\mathrm{SpO}_{2}(\%)$ & -0.034 & 0.004 & $-0.057--0.011$ & $\mathrm{SpO}_{2}$ & -0.039 & $<0.001$ & $-0.061--0.018$ \\
\hline Base excess (mmol/L) & -0.091 & $<0.001$ & $-0.124--0.058$ & Base excess & -0.114 & $<0.001$ & $-0.146--0.082$ \\
\hline Hemoglobin level (g/dL) & -0.056 & 0.180 & $-0.139-0.026$ & Hemoglobin level & -0.014 & 0.730 & $-0.096-0.067$ \\
\hline Platelet count $\left(10^{3} / \mathrm{mm}^{3}\right)$ & -0.005 & $<0.001$ & $-0.007--0.002$ & Platelet count & -0.005 & $<0.001$ & $-0.007--0.002$ \\
\hline INR & 0.294 & $<0.001$ & $0.158-0.430$ & INR & 0.313 & $<0.001$ & $0.176-0.450$ \\
\hline
\end{tabular}

Cl: Confidence interval; GAP: Glasgow Coma Scale, Age, and Systolic Blood Pressure; GCS: Glasgow Coma Scale; INR: International normalized ratio; MGAP: Mechanism, Glasgow Coma Scale, Age, and Systolic Blood Pressure; $\mathrm{SpO}_{2}$ : Peripheral oxygen saturation.

Table 5. Categorical analysis using the GAP model

\begin{tabular}{|c|c|c|c|}
\hline Variables & Odd ratio & $\mathbf{p}$ & 95\% Confidence interval \\
\hline \multicolumn{4}{|l|}{ Glasgow Coma scale } \\
\hline Moderate (19\&24 points) & 36.201 & $<0.001$ & $24.969-52.483$ \\
\hline Severe (1I-18 points) & 340.151 & $<0.001$ & $219.945-526.053$ \\
\hline \multicolumn{4}{|l|}{ Saturation (\%) } \\
\hline $90-81$ & 8.563 & $<0.001$ & $6.128-11.966$ \\
\hline $80-71$ & 30.669 & $<0.001$ & $|8.342-5| .28 \mid$ \\
\hline $70-61$ & 27.484 & $<0.001$ & $10.70 \mid-70.592$ \\
\hline $60-51$ & 61.325 & $<0.001$ & $15.295-245.875$ \\
\hline$<50$ & 10.310 & 0.042 & $1.083-98.142$ \\
\hline International normalized ratio > 1.5 & 18.737 & $<0.001$ & $14.127-24.850$ \\
\hline Platelet count $<100\left(10^{3} / \mathrm{mm}^{3}\right)$ & 4.351 & $<0.001$ & $3.350-5.651$ \\
\hline Base excess $(\mathrm{mmol} / \mathrm{L})<-6$ & 11.190 & $<0.001$ & $8.739-14.329$ \\
\hline
\end{tabular}

showed a significant association for predicting early mortality. The odds ratios became greater as the conditions measured indicated greater seriousness.

\section{DISCUSSION}

The aim of this research was to identify factors that can rapidly predict early mortality in trauma patients. The GAP, the MGAP, $\mathrm{SpO}_{2}$, base excess, platelet count, and INR were determined to be useful in this context. Of the 2 models using these parameters, the GAP was better than the MGAP.

Trauma-related mortality can be classified into 3 categories based on time; the causes of mortality differ between categories. The categories are immediate death (within minutes after injury), death within 24 hours, and in-hospital death after 24 hours. Most in-hospital mortality occurs during the second and third periods. Although factors directly related to trauma often cause mortality during the second period, the immediate effects of the accident decrease in the third period, during which death is caused by complications, such as sepsis and MOF ${ }^{[15]}$ Thus, as early and late trauma mortality differ in their etiologies, only 24-hour mortality was assessed in this study.

Most trauma-related mortality occurs within the first 24 to 48 hours. ${ }^{[6,17]}$ The survival of patients admitted to EDs is determined by the severity of the condition at the time of presentation and the promptness of treatment. Therefore, patients must be rapidly triaged, and the worst-affected treated quickly. Several studies have identified predictors of early mortality. However, these studies involved hospitalized patients or those with specific diseases, or employed tests that are not readily available..$^{[17,23-25]}$ One recent study proposed an early mortality prediction model for trauma patients based on clinical and laboratory values, as in the present study. ${ }^{[26]}$ This model was simple and included some variables that were similar to those used in our study for trauma mortality prediction. However, that study evaluated the 28-day mortality, not 
24-hour mortality. Furthermore, they used traumatic brain injury as a factor, which required image scan-taking times. In contrast, we evaluated only variables that can be rapidly measured, in order to facilitate rapid triage and thereby aid in initial management. Based on the categorical model outcomes using the GAP, we identified that a GAP $<19$ points, INR $>1.5$, platelets count $<100,000 / \mu \mathrm{L}$, base excess $<-6$, and saturation $<90 \%$ could be used as cutoff values for predicting early mortality. A previous study showed that these factors proved to be significant factors for in-hospital or 30-day mortality. ${ }^{[9,20-22]}$ In addition, the results indicated that they can also be used as the factors for early mortality.

Of the various TSSs, the RTS has been widely used since 1989. Although the RTS is simple to use, its predictive power is less than that of other recent TSSs. The ISS (developed in 1974) and the TRISS (developed in 1987) have found widespread use. Although the TRISS is more accurate, patients must be examined, and the required measurements are usually available only after several hours, rendering the system unsuitable as a predictor of early mortality. ${ }^{[6]}$ The ISS also requires that patients be examined. ${ }^{[3]}$ The GAP and MGAP are recent systems that do not require examination. ${ }^{[8,9]}$ Both systems are rapid and more predictive than the RTS. ${ }^{[9,27,28]}$ Thus, we chose the GAP and MGAP to predict early mortality. Previous studies on TSSs focused principally on in-hospital mortality. The GAP was studied in this context and, although short-term mortality was mentioned, this did not meet our definition of early mortality, as it was defined in terms of mortality in the ED or the operating room rather than in terms of time. ${ }^{[9]}$ One GAP validation study examined 24-hour mortality. However, the study included only patients with severe trauma; thus, not all trauma patients were included, and only 100 patients were evaluated. ${ }^{[27]}$ We found that when the GAP was used to evaluate all trauma patients admitted to the ED, the GAP predicted 24-hour mortality.

Many trauma patients die as a result of bleeding. We found that the percentage of patients who died from uncontrolled bleeding after trauma accounted for $30 \%$ to $35 \%$ of mortality during the acute stage. ${ }^{[29]}$ ATC develops during bleeding associated with tissue damage and resuscitation, and is caused by the consumption of coagulation factors and platelets, loss of red cells, blood dilution by fluid, hormonal and cytokineinduced changes, hypoxia, acidosis, hypothermia, and immune system activation. ${ }^{[4]}$ Although trauma patients may die from direct bleeding, death is further accelerated by ATC caused by bleeding and other factors. Many studies have been published on ATC, ${ }^{[4,10,11]}$ and have used various definitions of coagulopathy. ${ }^{[4]}$ In the present study, we used INR and platelet count to reflect ATC because these parameters can be easily measured (within 30 minutes at our hospital). Both were risk factors for 24-hour mortality. Prothrombin time-based assays (e.g., INR) and activated partial thromboplastin time (aPTT) are standard laboratory tests for ATC. ${ }^{[4]}$ However, both tests were developed to evaluate clotting factor deficiencies rather than the acquired coagulopathy associated with trauma. Therefore, these tests are inappropriate when measuring ATC. Some studies have used viscoelastic tests (thromboelastography and rotation thromboelastometry) in trauma settings. ${ }^{[30]}$ However, no standard viscoelastic test for ATC is yet available and, unlike INR and aPTT tests, viscoelastic tests are not performed in all hospitals. INR is more sensitive than the aPTT test when used to detect traumatic coagulation disorders. ${ }^{[3]}$ Other studies have also used INR to predict ATC. ${ }^{[32]}$ Platelets are responsible for primary hemostasis. A low platelet count is a risk factor for mortality. ${ }^{[33]}$ If ATC is promptly detected and treated, mortality can be reduced; active testing and treatment are needed. Previous research on the effect of ATC on early mortality has indicated that ATC increased such mortality, ${ }^{[20,25]}$ but these studies did not explore whether ATC predicted mortality. We found that ATC predicted early mortality. To the best of our knowledge, this is the first study to use both ATC and TSSs to predict early trauma-related mortality.

The base deficit (BD) is a prognostic marker that has been widely used since the 1960s. Recent studies have confirmed that BD significantly predicts mortality in trauma patients, despite recent advances in such treatment. ${ }^{[2]} A$ higher $B D$ suggests severe traumatic injury ${ }^{[34,35]}$ and is associated with complications, such as MOF, adult respiratory distress syndrome, acute lung injury, and renal failure coagulopathy. ${ }^{[3-38]}$ We also found that BD significantly predicted 24-hour mortality. Automated blood gas analysis yields fast results, particularly on point-of-care testing in EDs, and is simple to perform.

Saturation was a useful predictor of trauma mortality in an earlier study. ${ }^{[22]}$ The RTS (a TTS) used respiratory rate (RR) as a predictive variable. ${ }^{[5]}$ In trauma patients, the RR often fails to reflect ventilation or oxygenation status, as it is greatly affected by pain or psychological stress. Also, the normal range of RR is wide (10-29/minutes), and therefore the RTS may not accurately reflect actual ventilation or oxygenation. [39] In contrast, the objective $\mathrm{SpO}_{2}$ accurately reflects the ventilation/oxygenation status of trauma patients. We found that the RR did not predict 24-hour mortality, but saturation did.

Recent studies have evaluated trauma patient prognosis in terms of ED presentation time and found no difference in mortality between those admitted during business and nonbusiness hours ${ }^{[5,14,40]}$ because the medical resources available in hospitals with highly developed trauma systems do not vary significantly by the time of day. Such resources include 24-hour in-house surgeons and anesthesiologists and 24-hour emergency surgery/intervention suites. Our hospital is a tertiary care center for trauma patients, and we have access to such medical resources 24 hours a day. We found that presentation time did not affect mortality. Presentation time can affect ED waiting time or the incidence of adverse events, but in well-run hospitals, presentation time has no significant effect on early mortality after trauma. 
In this study, the mortality rate was $4.7 \%$, lower than that of other studies. This may be attributable to the exclusion of patients who were dead-on-arrival with or without attempted cardiopulmonary resuscitation. Also, we included those with mild trauma as well as those with serious trauma.

Our study had several limitations. First, the research was performed in a single center serving a Korean population only. Thus, this study may have a different age distribution and sex ratio than previous studies, and our results may not be completely applicable to all settings. Multicenter studies with different populations are required. Second, we did not include all of the clinical variables that could possibly affect trauma mortality, such as medical history, pre-hospital transfer time, or pre- or intra-hospital interventions. Third, the study was retrospective in nature. Hence, some data were missing, and the results may thus be compromised, despite our use of multiple imputation. Fourth, we enrolled only adults $>16$ years of age. Pediatric patients were excluded because they have unique physiological characteristics. In future, early mortality in pediatric patients should be studied.

\section{Conclusion}

The GAP, MGAP, SpO ${ }_{2}$, base excess, platelet count, and INR usefully predicted early mortality among trauma patients. The GAP model is simpler and more accurate than the MGAP model. We believe that our GAP-based model will be useful for early triage and appropriate initial management of trauma patients.

\section{Acknowledgements}

The trauma registry was originally developed as a part of Emergency Department-based Injury In-depth Surveillance conducted by the Korea Centers for Disease Control and Prevention.

\section{Conflict of interest: None declared.}

\section{REFERENCES}

1. Niles SE, McLaughlin DF, Perkins JG, Wade CE, Li Y, Spinella PC, et al. Increased mortality associated with the early coagulopathy of traumain combat casualties. J Trauma 2008;64:1459-63. [CrossRef]

2. Murray CJ, Vos T, Lozano R, Naghavi M, Flaxman AD, Michaud C, et al. Disability-adjusted life years (DALYs) for 291 diseases and injuries in 21 regions, 1990-2010: a systematic analysis for the Global Burden of Disease Study 2010. Lancet 2012;380:2197-223. [CrossRef]

3. Baker SP, O'Neill B, Haddon W Jr, Long WB. The injury severity score: a method for describing patients with multiple injuries and evaluating emergency care. J Trauma 1974;14:187-96. [CrossRef]

4. Cap A, Hunt B. Acute traumatic coagulopathy. Curr Opin Crit Care 2014;20:638-45. [CrossRef]

5. Ono Y, Ishida T, Iwasaki Y, Kawakami Y, Inokuchi R, Tase C, et al. The off-hour effect on trauma patients requiring subspecialtyintervention at a community hospital in Japan: a retrospective cohort study. Scand J Trauma Resusc Emerg Med 2015;23:20. [CrossRef]
6. Boyd CR, Tolson MA, Copes WS. Evaluating trauma care: the TRISS method. Trauma Score and the Injury Severity Score. J Trauma 1987;27:370-8. [CrossRef]

7. Champion HR, Sacco WJ, Copes WS, Gann DS, Gennarelli TA, Flanagan ME. A revision of the Trauma Score. J Trauma 1989;29:623-9.

8. Sartorius D, Le Manach Y, David JS, Rancurel E, Smail N, Thicoïpé M, Mechanism, glasgow coma scale, age, and arterial pressure (MGAP): a new simple prehospital triage score to predict mortality in traumapatients. Crit Care Med 2010;38:831-7. [CrossRef]

9. Kondo Y, Abe T, Kohshi K, Tokuda Y, Cook EF, Kukita I. Revised trauma scoring system to predict in-hospital mortality in the emergency department: Glasgow Coma Scale, Age, and Systolic Blood Pressure score. Crit Care 2011;15:R191. [CrossRef]

10. Brohi K, Singh J, Heron M, Coats T. Acute traumatic coagulopathy. J Trauma 2003;54:1127-30. [CrossRef]

11. Maegele M, Paffrath T, Bouillon B. Acute traumatic coagulopathy in severe injury: incidence, riskstratification, and treatment options. Dtsch Arztebl Int 2011;108:827-35.

12. Di Bartolomeo S. The 'off-hour' effect in trauma care: a possible quality indicator with appealing characteristics. Scand J Trauma Resusc Emerg Med 2011;19:33. [CrossRef]

13. Jneid H, Fonarow GC, Cannon CP, Palacios IF, Kilic T, Moukarbel GV,et al. Impact of time of presentation on the care and outcomes of acute myocardial infarction. Circulation 2008;117:2502-9. [CrossRef]

14. Laupland KB, Ball CG, Kirkpatrick AW. Hospital mortality among major trauma victims admitted on weekends and evenings: a cohort study. J Trauma Manag Outcomes 2009;3:8. [CrossRef]

15. Sobrino J, Shafi S. Timing and causes of death after injuries. Proc (Bayl Univ Med Cent) 2013;26:120-3. [CrossRef]

16. Sauaia A, Moore FA, Moore EE, Moser KS, Brennan R, Read RA, et al. Epidemiology of trauma deaths: a reassessment. J Trauma 1995;38:18593. [CrossRef]

17. Wang H, Robinson RD, Moore B, Kirk AJ, Phillips JL, Umejiego J, et al. Predictors of early versus late mortality in pelvic trauma patients. Scand J Trauma Resusc Emerg Med 2016;24:27. [CrossRef]

18. White IR, Royston P, Wood AM. Multiple imputation using chained equations: Issues and guidance for practice. Stat Med 2011;30:377-99.

19. DeLong ER, DeLong DM, Clarke-Pearson DL. Comparing the areas under two or more correlated receiver operating characteristic curves: a nonparametric approach. Biometrics 1988;44:837-45. [CrossRef]

20. Maegele M, Lefering R, Yucel N, Tjardes T, Rixen D, Paffrath T, et al. Early coagulopathy in multiple injury: an analysis from the GermanTrauma Registry on 8724 patients. Injury 2007;38:298-304.

21. Ibrahim I, Chor WP, Chue KM, Tan CS, Tan HL, Siddiqui FJ, et al. Is arterial base deficit still a useful prognostic marker in trauma? A systematic review. Am J Emerg Med 2016;34:626-35. [CrossRef]

22. Huber-Wagner S, Stegmaier J, Mathonia P, Paffrath T, Euler E, Mutschler $\mathrm{W}$, et al. The sequential trauma score - a new instrument for the sequential mortality prediction in major trauma. Eur J Med Res 2010;15:185-95.

23. Gerdin M, Roy N, Khajanchi M, Kumar V, Dharap S, Felländer-Tsai L, et al. Predicting early mortality in adult trauma patients admitted to three public university hospitals in urban India: a prospective multicentre cohort study. PLoS One 2014;9:e105606. [CrossRef]

24. Hampton DA, Lee TH, Diggs BS, McCully SP, Schreiber MA. A predictive model of early mortality in trauma patients. Am J Surg 2014;207:642-7. [CrossRef]

25. Mitra B, Cameron PA, Mori A, Fitzgerald M. Acute coagulopathy and early deaths post major trauma. Injury 2012;43:22-5. [CrossRef]

26. Kunitake RC, Kornblith LZ, Cohen MJ, Callcut RA. Trauma Early 
Mortality Prediction Tool (TEMPT) for assessing 28-day mortality. Trauma Surg Acute Care Open 2018;3:e000131. [CrossRef]

27. Ahun E, Köksal Ö, Sığırlı D, Torun G, Dönmez SS, Armağan E. Value of the Glasgow coma scale, age, and arterial blood pressure score for predicting the mortality of major trauma patients presenting to the emergency department. Ulus Travma Acil Cerrahi Derg 2014;20:241-7. [CrossRef]

28. Baghi I, Shokrgozar L, Herfatkar MR, Nezhad Ehsan K, Mohtasham Amiri Z. Mechanism of Injury, Glasgow Coma Scale, Age, and Systolic Blood Pressure: A New Trauma Scoring System to Predict Mortality in Trauma Patients. Trauma Mon 2015;20:e24473. [CrossRef]

29. Evans JA, van Wessem KJ, McDougall D, Lee KA, Lyons T, Balogh ZJ. Epidemiology of traumatic deaths: comprehensive population-based assessment. World J Surg 2010;34:158-63. [CrossRef]

30. Johansson PI, Stissing T, Bochsen L, Ostrowski SR. Thrombelastography and tromboelastometry in assessing coagulopathy in trauma. Scand J Trauma Resusc Emerg Med 2009;17:45. [CrossRef]

31. Yuan S, Ferrell C, Chandler WL. Comparing the prothrombin time INR versus the APTT to evaluate the coagulopathy of acute trauma. Thromb Res 2007;120:29-37. [CrossRef]

32. Peltan ID, Vande Vusse LK, Maier RV, Watkins TR. An International Normalized Ratio-Based Definition of Acute Traumatic Coagulopathy Is Associated With Mortality, Venous Thromboembolism, and Multiple Organ Failure After Injury. Crit Care Med 2015;43:1429-38. [CrossRef] 33. Stansbury LG, Hess AS, Thompson K, Kramer B, Scalea TM, Hess JR.
The clinical significance of platelet counts in the first 24 hours after severe injury. Transfusion 2013;53:783-9. [CrossRef]

34. Sinert R, Zehtabchi S, Bloem C, Lucchesi M. Effect of normal saline infusion on the diagnostic utility of base deficit in identifying major injury in trauma patients. Acad Emerg Med 2006;13:1269-74. [CrossRef]

35. Mofidi M, Hasani A, Kianmehr N. Determining the accuracy of base deficit in diagnosis of intra-abdominal injury in patients with blunt abdominal trauma. Am J Emerg Med 2010;28:933-6. [CrossRef]

36. Sauaia A, Moore FA, Moore EE, Haenel JB, Read RA, Lezotte DC. Early predictors of postinjury multiple organ failure. Arch Surg 1994;129:3945. [CrossRef]

37. Davis JW, Parks SN, Kaups KL, Gladen HE, O'Donnell-Nicol S. Admission base deficit predicts transfusion requirements and risk of complications. J Trauma 1996;41:769-74. [CrossRef]

38. Eberhard LW, Morabito DJ, Matthay MA, Mackersie RC, Campbell AR, Marks JD, et al. Initial severity of metabolic acidosis predicts the development of acute lung injury in severely traumatized patients. Crit Care Med 2000;28:125-31. [CrossRef]

39. Raux M, Thicoïpé M, Wiel E, Rancurel E, Savary D, David JS, et al. Comparison of respiratory rate and peripheral oxygen saturation to assess severity in trauma patients. Intensive Care Med 2006;32:405-12.

40. Arbabi S, Jurkovich GJ, Wahl WL, Kim HM, Maier RV. Effect of patient load on trauma outcomes in a Level I trauma center. J Trauma 2005;59:815-8. [CrossRef]

\title{
ORIJINAL ÇALIŞMA - ÖZET
}

\section{Travma hastalarında erken mortaliteyi öngören faktörler}

\section{Dr. Won Young Yong Jin, ${ }^{1}$ Dr. Jin Hee Jeong, ${ }^{1,2}$ Dr. Dong Hoon Kim, ${ }^{1}$ Dr. Tae Yun Kim, ${ }^{1}$ Dr. Changwoo Kang, Dr. Soo Hoon Lee, ${ }^{1}$ Dr. Sang Bong Lee, ${ }^{1}$ Dr. Seong Chun Kim, ${ }^{3}$ Dr. Yong Joo Park, ${ }^{3}$ Dr. Daesung Lim ${ }^{3}$}

\begin{abstract}
'Gyeongsang Ulusal Üniversitesi Tıp Fakültesi, Acil Tıp Anabilim Dalı, Jinju-si, Gyeongsangnam-do-Kore Cumhuriyeti
${ }^{2}$ Gigeongsang Sağlık Bilimleri Enstitüsü, Gyeongsang Ulusal Üniversitesi Tıp Fakültesi, Acil Tıp Anabilim Dalı, Jinju-si, Gyeongsangnam-do-Kore Cumhuriyeti ${ }^{3}$ Gyeongsang Ulusal Üniversitesi Tıp Fakültesi ve Gyeongsang Ulusal Üniversitesi Changwon Hastanesi, Acil Tıp Anabilim Dalı, Changwon, GyeongsangnamKore Cumhuriyeti

AMAÇ: Bu çalışmanın amacı travma hastalarında mortaliteyi erkenden öngören faktörleri tanımlamaktır.

GEREÇ VE YÖNTEM: Bu çalışma 201 I Temmuz ile 2016 Temmuz arasında 6.288 travma hastasında gerçekleştirildi. Bir ileriye yönelik travma kayıt sisteminden alınan değişkenler arasında aşağıdakiler tek veya kombinasyon hali hastaların cinsiyeti, yaşı; Glasgow Koma Ölçeği Skoru, yaş ve sistolik kan basıncı (SKB) kombinasyonu (GYS); travmanın mekanizması, Glasgow Koma Skoru, yaş ve SKB kombinasyonu (MGYS); solunum hızı; periferik oksijen doygunluğu $\left(\mathrm{SpO}_{2}\right.$ değeri); Glasgow Koma Ölçeği Skoru; laboratuvar değişkenleri ve başvuru zamanı. Bu değişkenler ile erken mortalite arasındaki ilişkileri araştırmak için lojistik regresyon analizi kullanıldı.

BULGULAR: Yirmi dört saat içinde toplam 296 (\%4.6) hasta hayatını kaybetti. Tek değişkenli regresyon analizinde yaş, GYS, SKB, alkali fazlalığı, hemoglobin düzeyi, trombosit sayısı, INR ve başvuru zamanı erkenden mortaliteyi öngörmüştür. Çok değişkenli regresyon analizi de GYS, MGYS, $\mathrm{SpO}_{2}$, alkali fazlalığı, trombosit sayısı ve INR birbirlerinden bağımsız olarak mortaliteyi öngörmüştür. GYS ve MGYS modelleri için alıcı iletim eğrisi altındaki alanların karşılaştırmaları GYS modelinin üstünlüğünü ortaya koymuştur.

TARTIŞMA: GYS modeli, $\mathrm{SpO}_{2}$, alkali fazlalığı, trombosit sayısı ve INR travma hastalarında erkenden mortaliteyi öngörmüştür. Anahtar sözcükler: Akut travmatik koagülopati; alkali fazlalığı; mortalite; periferik oksijen doygunluğu; travma; travma skorlama sistemi.
\end{abstract}

Ulus Travma Acil Cerrahi Derg 2018;24(6):532-538 doi: 10.5505/tjtes.2018.29434 